\title{
Konfiskacija karlovačke tekstilne industrije (1945. - 1946.)
}

\author{
NIKOLA PERKOVIĆ \\ Zagreb, Hrvatska \\ nikola.perkovic50@gmail.com \\ Autor na temelju arhivskoga gradiva i literature opisuje i objašnjava gospodar- \\ ske procese na području Karlovca i njegove uže okolice uvjetovane političkim \\ odlukama neposredno nakon Drugoga svjetskog rata 1945. i 1946. godine. \\ Ključne riječi: Karlovac; 1945. - 1946.; tekstilna industrija; konfiskacija
}

\section{Uvod}

Rad je napisan na osnovi arhivskih izvora i literature. Arhivski izvori odnose se na gospodarske procese u Karlovcu i njegovoj užoj okolici neposredno nakon Drugoga svjetskog rata, a kao najvažnije arhivske fondove navest ću one Zavoda za statistiku i Zemaljske uprave narodnih dobara Narodne Republike Hrvatske od 1945. do 1946., koji se čuvaju u Hrvatskom državnom arhivu u Zagrebu. Neizostavna literatura korištena u radu, neophodna za razumijevanje razdoblja komunističke Jugoslavije, jesu knjige Hrvatska u Jugoslaviji 1945. - 1991. Od zajedništva do razlaza Zdenka Radelića i Hrvatska moderna povijest akademika Dušana Bilandžića. Spomenuta djela od velike su važnosti i prilikom povijesnih istraživanja toga razdoblja radi razumijevanja širega konteksta unutar kojega su se odvijali određeni procesi - gospodarski, politički ili kulturni - na nižim razinama. Od korištenih radova koji su iznimno važni u pogledu obrade gospodarske situacije u Jugoslaviji nakon rata i provođenja mjera podržavljenja imovine privatnih vlasnika spomenut ću članke Tomislava Anića „Normativni okvir podržavljenja imovine u Hrvatskoj/Jugoslaviji 1944.1946.” i „Podržavljenje stranog kapitala u Hrvatskoj/Jugoslaviji 1945.-1946. na primjeru poduzeća Thonet Mundus d.d. u većinskome švicarskom vlasništvu”, objavljene u Časopisu za suvremenu povijest. 
Neposredno nakon završetka Drugoga svjetskog rata na prostoru Jugoslavije novouspostavljena vlast Komunističke partije Jugoslavije (KPJ) postavljala je političke, zakonodavne i institucionalne okvire čiji će cilj u budućnosti biti ustoličiti komunizam kao dominantni političko-ekonomski sustav društvenoga uređenja i organizacije života uopće. Izgrađivao se komunizam staljinističkoga tipa s obzirom na ulogu i utjecaj Saveza Sovjetskih Socijalističkih Republika, čiji je model društveno-političkoga uređenja KPJ slijedila. Bit komunističkoga poimanja organizacije društveno-političkoga života čini revolucionarno djelovanje koje je željelo ukidanje klasnih podjela i stavljanje svakoga oblika privatnoga vlasništva pod kontrolu države, odnosno partijskih i državnih organa Demokratske Federativne Jugoslavije (DFJ).

Dugoročan cilj KPJ djelovanjem nakon završetka Drugoga svjetskog rata bila je uspostava kolektivnoga vlasništva i državnoga poduzetništva, što su prema marksističkoj teoriji temelji socijalizma i njegova gospodarskoga sustava. ${ }^{1}$ Radi stvaranja komunističkoga društvenog sustava KPJ je negirala i marginalizirala temeljne građanske vrijednosti poput pluralističkoga političkog sustava, privatnoga vlasništva i građanskih sloboda. Nasuprot tome uveden je sustav razvlašćivanja vlasnika privatnoga kapitala, što je bilo u suprotnosti s ratnom taktikom KPJ. ${ }^{2}$ Postojala je i ovisnost sudova, koji su u DFJ, i poslije u Federativnoj Narodnoj Republici Jugoslaviji (FNRJ), bili poluga provođenja zamisli partijskih organa. Oni su u svojim odlukama privatne nositelje kapitala najčešće prikazivali kao suradnike ustaških vlasti te ih na taj način predstavljali kao protivnike socijalističke ideje i olakšali podržavljenje privatne imovine, čiji je cilj bio učiniti nositelje privatnoga kapitala ovisnima o partijskim i državnim organima. Radi lakšega razumijevanja tematike rada, čiji će naglasak biti stavljen na podržavljenje karlovačke tekstilne industrije i općenito na posredan prikaz funkcioniranja gospodarstva u cjelini, potrebno je analizirati programsku koncepciju KPJ na temelju koje se razvlašćivalo privatne vlasnike i stavljalo kontrolu njihove imovine u nadležnost novouspostavljene vlasti DFJ.

Iako KPJ za vrijeme Drugoga svjetskog rata nije otvoreno najavljivala oduzimanje imovine, tj. promjenu vlasništva nad imovinom, namjere su se nakon rata znatno promijenile. ${ }^{3}$ Program KPJ prihvaćen 1920. na 2. partijskom kongresu u Vukovaru odredio je ciljeve u pogledu regulacije vlasništva nad sredstvima za proizvodnju, odnosno segmentima kojima se stvara akumulacija kapitala potrebna za izgradnju socijalizma. Program naglašava važnost suštinske promjene položaja radničke klase, koja će ga poboljšati preuzimanjem i ovladavanjem sredstvima proizvodnje. U Programu se dalje ističe: „Da bi se po

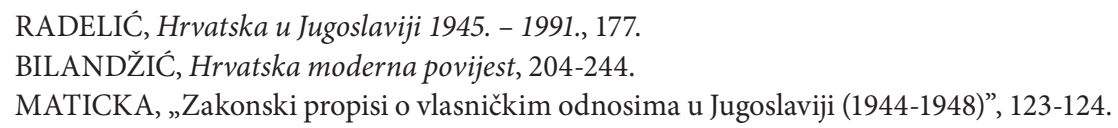


osvojenju političke vlasti podigla proizvodnja, diktatura proleterijata treba da izvrši eksproprijaciju krupnih kapitalista i veleposednika, da sredstva za proizvodnju i saobraćaj pretvori u kolektivnu svojinu radničke države." Pored teorijski definiranih stajališta Program donosi i naputak čijim će se provođenjem omogućiti učinkovita uspostava kontrole radničke klase nad sredstvima za proizvodnju. Prvi cilj bio je preuzimanje kontrole nad državnim tijelima koja se bave organizacijom gospodarstva, napose nacionalizacija banaka, velikih industrijskih grana i poduzeća te malih posjeda. O generalnoj liniji provođenja teorijskih i praktičnih postavki Programa govori nam sljedeće stajalište: "Što se tiče manjih preduzeća, proletarijat će ih socijalizirati malo pomalo, vodeći računa o njihovoj veličini i društvenoj korisnosti.' Iz navedenog jasno proizlazi kako je stajalište Komunističke partije Jugoslavije kada se radilo o vlasništvu bilo nedvosmisleno." ${ }^{5}$

Nadalje, KPJ je tijekom rata vodila i upravljala planovima i formulirala političku strategiju Narodnooslobodilačkoga pokreta (NOP). Upravo je potreba omasovljenja NOP-a primorala na revidiranje stajališta u vezi s rješavanjem imovinsko-pravnih odnosa. Mobiliziranje stanovništva za borbu protiv okupatora u okviru NOP-a poprimilo je umjereniji karakter i zbog toga što su politički protivnici u zemlji i izvan nje upućivali na komunističku prirodu NOP-a koju je KPJ u vrijeme rata željela sakriti. Ublažavanjem stajališta iznesenih u Programu želio se negirati revolucionarni karakter NOP-a radi uspostavljanja dobrih odnosa sa Saveznicima. O suprotstavljanju prikazivanju revolucionarnoga karaktera NOP-a najbolje govori Izjava o ciljevima i načelima Narodnooslobodilačke borbe koju su 26. svibnja 1943. objavili Inicijativni odbor Zemaljskoga antifašističkog vijeća narodnog oslobođenja Hrvatske (ZAVNOH) i Glavni štab Narodnooslobodilačke vojske i partizanskih odreda Hrvatske. Izjava je isticala da politički protivnici Narodnooslobodilačke borbe poput ustaša, četnika, predstavnika Hrvatske seljačke stranke te izbjegličke vlade u Londonu pogrešno prikazuju ciljeve NOP-a. ${ }^{6} \mathrm{U}$ želji za neutralizacijom „dezinformacija” koje se šire iz suprotstavljenih političkih centara, u Izjavi se kaže: „Narodno-Oslobodilački Pokret ne uvodi nikakvih radikalnih promjena u pogledu društvenog (socijalnog) života, osim zamjene reakcionarnih općinskih uprava, načelnika i žandara, koji su se stavili u službu okupatora, s pravim, slobodnom narodnom voljom izabranim predstavništvima, koja imaju istinski demokratsko narodni karakter. Sve najvažnije mjere, kako u društvenom životu, tako i državnoj organizaciji rješavat će nakon rata 25-62.

Isto; ANIĆ, „Normativni okvir podržavljenja imovine u Hrvatskoj/Jugoslaviji 1944.-1946.”, ANIĆ, „Normativni okvir podržavljenja imovine u Hrvatskoj/Jugoslaviji 1944.-1946.”, 25-62. Isto. 
predstavnici koje izabere narod."7 Izjava je trebala poslužiti i kao podloga za stjecanje povoljnijega položaja NOP-a, i u zemlji i u inozemstvu, isticanjem jednakosti demokratskih prava i prava vlasništva. U kontekstu demokratskih prava i prava vlasništva u Izjavi stoji sljedeće: „Narodno-Oslobodilački Pokret bori se za socijalna i demokratska prava, te je prema tome daleko od svakog nasilja i nezakonitosti. On priznaje nepovredivost privatnog vlasništva kao i najšire mogućnosti ispoljavanja inicijative $u$ industriji i ostalim privrednim djelatnostima." ${ }^{8}$ nastavku ću detaljnije objasniti neke osnovne zakone i mjere podržavljenja ključne za razumijevanje tematike rada.

Analizirajući pravni aspekt, među mjere podržavljenja imovine svrstavamo konfiskaciju i nacionalizaciju. Konfiskacija, kao najizrazitija mjera kaznenoga karaktera, oduzimanje je dijela ili cjelokupne imovine, koja bez ikakve naknade prelazi u vlasništvo države. ${ }^{9}$ Nadalje, nacionalizacijom je gotovo cjelokupna privreda prešla u državno vlasništvo. Pored gospodarskoga i pravnoga, nacionalizaciju možemo promatrati i sa sociološkoga stajališta. Neposredna posljedica razvlašćivanja vlasnika imovine nacionalizacijom bilo je smanjenje njihove društvene privilegiranosti te pogoršanje životnih uvjeta uslijed nemogućnosti dobivanja naknade za oduzetu imovinu, ili dobivanja naknade koja nije odgovarala vrijednosti nacionalizirane imovine. ${ }^{10}$

Promjene vlasništva nad imovinom neposredno nakon Drugoga svjetskog rata zasnivane su na Uredbi o vojnim sudovima od 24. svibnja 1944., Odluci o prijelazu u državno vlasništvo neprijateljske imovine, o državnoj upravi nad imovinom neprisutnih lica i o sekvestru nad imovinom koju su okupatorske vlasti prisilno otuđile od 21. studenog 1944., Zakonu o suzbijanju nedopuštene špekulacije i privredne sabotaže od 23. travnja 1945., Odluci o zaštiti nacionalne časti Hrvata i Srba u Hrvatskoj od 24. travnja 1945., Zakonu o zabrani izazivanja nacionalne, rasne i vjerske mržnje i razdora od 24. svibnja 1945. Zakonu o oduzimanju ratne dobiti stečene za vrijeme neprijateljske okupacije od 24. svibnja 1945., Zakonu o konfiskaciji imovine i izvršenju konfiskacije od 9. lipnja 1945., Zakonu o kursevima za povlačenje okupacijskih novčanica i reguliranju obaveza na području Hrvatske od 21. lipnja 1945., Zakonu o suzbijanju nedopuštene trgovine, nedopuštene špekulacije i privredne sabotaže od 11. srpnja 1946., Zakonu o krivičnim djelima protiv naroda i države od 25. kolovoza 1945., koji je dopunjen 16. srpnja 1946., Zakonu o oduzimanju državljanstva oficirima i podoficirima bivše jugoslavenske vojske koji se ne žele vratiti u domovinu, pripadnicima vojnih formacija koji su služili okupatoru

\footnotetext{
Isto, 29

Isto.

Isto, 25-62.

Isto.
} 
i pobjegli u inozemstvo, te osobama koje su pobjegle u inozemstvo nakon oslobođenja od 23. kolovoza 1945., s izmjenama toga zakona od 23. listopada 1946., na temelju kojih su provođene zapljene, te Zakonu o agrarnoj reformi i kolonizaciji od 23. kolovoza 1945., Zakonu o provođenju agrarne reforme i kolonizacije na području Federalne Hrvatske od 24. studenog 1945. i Zakonu o nacionalizaciji privatnih privrednih poduzeća iz 1946. godine. ${ }^{11}$ Svrha svih spomenutih zakona bilo je oduzimanje imovine vlasniku bez obzira na to slaže li se on s tim ili ne.

Za praktičnu provedbu Odluke o prijelazu u državno vlasništvo neprijateljske imovine, o državnoj upravi nad imovinom neprisutnih lica i o sekvestru nad imovinom koju su okupatorske vlasti prisilno otuđile od 21. studenog 1944. bila je zadužena Zemaljska komisija za utvrđivanje zločina okupatora i njihovih pomagača. Institucije zadužene za provedbu Odluke koju je Povjereništvo unutrašnjih poslova ZAVNOH-a dostavilo 19. ožujka 1945. bili su oblasni i okružni narodnooslobodilački odbori. O načinu rada tih institucija dovoljno govori činjenica da za prijelaz imovine u državno vlasništvo nije bila potrebna sudska odluka, nego pismeno rješenje upravnoga odjela okružnoga narodnooslobodilačkog odbora. ${ }^{12}$

Veliku važnost ima Odluka o zaštiti nacionalne časti Hrvata i Srba u Hrvatskoj Predsjedništva ZAVNOH-a od 24. travnja 1945. godine. Njome se sankcionirala poslovna i prijateljska suradnja s pripadnicima neprijateljske vlasti i vojske, a kažnjavala se i služba u tijelima državne uprave Nezavisne Države Hrvatske (NDH) za vrijeme četverogodišnjega rata. Odlukom je za prekršitelje bio predviđen izgon, a završna bilanca pokazuje da je na temelju presuda sudova za zaštitu nacionalne časti konfiscirano 117 industrijskih poduzeća i 189 posjeda. Odluka o zaštiti nacionalne časti Hrvata i Srba u Hrvatskoj se praktično primjenjivala četiri mjeseca, nakon čega je Predsjedništvo Narodnoga sabora Federalne Hrvatske donijelo Zakon o izmjenama Odluke o zaštiti nacionalne časti Hrvata i Srba u Hrvatskoj, čijom regulativom nadležnost posebnih sudova koji su dotad bili zaduženi za provedbu Odluke prelazi na okružne narodne sudove. ${ }^{13}$

Prema Zakonu o konfiskaciji imovine i izvršenju konfiskacije od 9. lipnja 1945., plijenila se imovina onih koje je NOP za vrijeme rata sudskom odlukom osudio na smrt ili izvansudski smaknuo ili su pak, u strahu od odmazde pobjednika, potkraj rata pobjegli u inozemstvo. Informacije izrečene na 3. konferenciji predstavnika Državne uprave narodnih dobara (DUND) i zemaljskih uprava narodnih dobara (ZUND) 30. i 31. prosinca 1945., koje nisu konačne,

\footnotetext{
11 RADELIĆ, Hrvatska u Jugoslaviji 1945. - 1991., 180, 189.

12 Isto, 180.

13 Isto, 181.
} 
u Hrvatskoj je predano 8025 prijedloga za zapljenu. Od svih zemalja FNRJ Hrvatska je predvodila po broju prijedloga. Slijedi Bosna i Hercegovina, gdje je bilo 7500 prijedloga, zatim Srbija sa 5420 prijedloga, ali prema podacima za samo neke okruge i bez Autonomne Pokrajine Vojvodine i Autonomne oblasti Kosmeta, te Slovenija sa 5901 prijedlogom. ${ }^{14}$ Intencija toga zakona bila je pojednostavnjenje procedure konfiskacije imovine tijekom i nakon rata, gdje bi se kao osnova za konfiskaciju koristio samo jedan zakonski tekst. Jednim zakonskim tekstom koji bi vrijedio za sve oblike imovine i pojednostavnjenjem procedure spriječila bi se konfiskacija imovine po različitim kriterijima i postupcima koja je neizbježno vodila do pogrešaka. ${ }^{15}$

Konfiskacija imovine određena je Zakonom o konfiskaciji imovine i izvršenju konfiskacije kao prinudno oduzimanje bez naknade, u korist države. Moguća je bila konfiskacija cjelokupne imovine ili točno određenoga dijela koji je osobno vlasništvo ili osobni udio u zajedničkoj imovini s drugim osobama. ${ }^{16}$ Sva imovina oduzeta na taj način ulazila je u Jedinstveni narodnooslobodilački fond. ${ }^{17}$

Gospodarske prilike u Karlovcu i okolici između dva svjetska rata

Šira društvena situacija te zakoni koji su omogućili podržavljenje kao jednu od temeljnih premisa marksističke revolucionarne misli bitni su nam za razumijevanje onoga što ću pokušati prikazati u nastavku rada, a to je proces konfiskacije tekstilne industrije Karlovca i njegove uže okolice.

Važnost obrade konfiskacije tekstilne industrije logički se nameće ako uzmemo u obzir sljedeće činjenice. Od početka 1930. pa sve do početka Drugoga svjetskog rata postotak tekstilnih radnika bio je u rasponu od 11,1 \% do $14,9 \%$, pri čemu su više od $60 \%$ činili seljaci-radnici. Gledajući nacionalnu razinu, na izvoz tekstilne industrije otpadalo je oko 49 \% od ukupnoga izvoza monarhističke Jugoslavije. ${ }^{18}$

Razdoblje između dvaju svjetskih ratova karakteristično je po financijskoj stabilnosti poslovanja tekstilne industrije. Uspješnost njezina poslovanja narušava se nakon vojnoga napada Njemačke na Austriju, Čehoslovačku i njezino sudetsko područje, što se ponajprije očituje u ograničenom uvozu tekstilnih sirovina, poluproizvoda i pamučnoga prediva u odnosu na razdoblje od početka 1930. godine. Teritorijalne promjene koje su se 1938. dogodile u srednjoj

\footnotetext{
MIKOLA, Zaplembe premoženja v Sloveniji 1943-1952, 178.

MATICKA, „Zakonski propisi o vlasničkim odnosima u Jugoslaviji (1944-1948)”, 133.

AKMADŽA, Oduzimanje imovine Katoličkoj crkvi, 127.

ANIĆ, „Podržavljenje stranog kapitala u Hrvatskoj/Jugoslaviji 1945.-1946.”, 819-832.

ŠIMONČIĆ-BOBETKO, Industrija Hrvatske 1918. do 1941. godine, 273.
} 
Europi prilično su utjecale na tekstilni uvoz. ${ }^{19}$ Uslijed njemačke vojne okupacije Austrije, Čehoslovačke i Sudeta te preorijentacije tvornica sirovina na proizvodnju za vojne potrebe, Hrvatska se za nabavu tekstilnih sirovina i poluproizvoda morala orijentirati na englesko tržište, koje je bilo znatno skuplje u odnosu na tržište zemalja srednje Europe. ${ }^{20}$

Nadalje, valja naglasiti da je uslijed nestabilnosti tržišta kao posljedice nagovještaja početka Drugoga svjetskog rata cijena gotovih tekstilnih proizvoda porasla između $10 \%$ i $12 \% .{ }^{21}$

Karlovačku gospodarsku situaciju u međuraću karakteriziraju financijska stabilnost i prosperitet. Neposredno nakon završetka Prvoga svjetskog rata pojavljuje se velika mogućnost razvoja svih industrijskih grana uslijed proširenja tržišta na čitavo područje novostvorene jugoslavenske države, kao i prekida trgovačkih veza s industrijski razvijenim dijelovima bivše Austro-Ugarske Monarhije. ${ }^{22}$ Treba istaknuti da je grad osiguravao povoljne uvjete za razvitak industrije. Pored besplatnoga zemljišta, tijekom duljega razdoblja oslobađao je poduzetnike gradskih poreza, a onima koji su zapošljavali preko dvjesto radnika davao je i besplatnu struju. ${ }^{23}$ Zbog toga je Karlovac bio poželjno odredište industrijalcima diljem zemlje u potrazi za brzim ostvarenjem profita. Početkom 1930. industrijalizacija Karlovca zastala je te je tijekom Velike krize propalo nekoliko većih tvornica i niz obrtničkih poduzeća. Tekstilna industrija i njezin izvanredno povoljan razvoj do 1938. omogućili su da se Karlovac i okolica u međuraću ne moraju suočavati s velikim problemom nezaposlenosti radnika-seljaka, osobito žena. ${ }^{24}$

Novoustrojena je vlast neposredno nakon završetka Drugoga svjetskog rata prionula na cjelokupan preustroj sustava na političkoj, ekonomskoj i kulturnoj osnovi, što je rezultiralo stavljanjem tekstilne industrije pod kontrolu partijskih vlasti, a ona je, kada analiziramo stanje u međuratnom razdoblju, većinom bila prosperitetna i ustrojena na zdravim financijskim temeljima s iznimkom razdoblja Velike krize.

Valja napomenuti da u nastavku neću obuhvatiti temeljne postavke razvoja karlovačke tekstilne industrije tijekom cijele njezine povijesti, nego samo razdoblje iz naslova rada, kada je konfiskacija provođena s izrazitom efikasnošću, te ću u tom pogledu taksativno obraditi poduzeća za koja je pronađena arhiv-

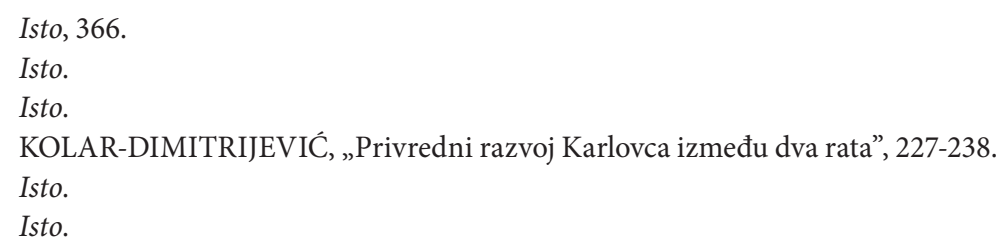


ska građa i dokumentacija, a koja su bila izvrgnuta spomenutom tretmanu partijskih i državnih organa DFJ i FNRJ.

\section{Vuna d.d. / Tekstilne tvornice d.d. (koncern Ilić)}

Poduzeće Vuna d.d. njemačkoga poduzetnika Adolfa Romera iz Leobena osnovano je 1922. sa sjedištem u Karlovcu. Temeljna glavnica poduzeća iznosila je 8.000.000 kruna. Poduzeće 1925. prelazi u vlasništvo koncerna Koste Ilića i sinova iz Beograda. Ondašnja glavnica od 3.750.000 dinara povećava se ulaskom braće Ilić u vlasničku strukturu poduzeća za 750.000 dinara, što kumulativno čini glavnicu od 4.500.000 dinara podijeljenih na 45000 akcija po donosiocima od 100 dinara. ${ }^{25}$ Godine 1925 . dovršena je izgradnja poduzeća te su proizvodni pogoni pušteni u rad, a kao temeljne djelatnosti u upitnom listu Statističkoga ureda pri Predsjedništvu Narodne Republike (NR) Hrvatske navode se proizvodnja vunenih tkanina, izrada štofova za odijela i kapute, deka za bolnice, vojsku i privatnu upotrebu. ${ }^{26}$

Tvornica je bila smještena u Turnju, 4,5 km od Karlovca na ušću Mrežnice u Koranu, te je na tom teritoriju imala sedamnaest proizvodnih postrojenja uz vlastiti električni pogon koji je omogućavala vodena snaga dviju spomenutih rijeka. U okviru koncerna Ilić uz Vunu d.d. bile su i Tekstilne tvornice d.d. ${ }^{27}$, prije rata poznate pod nazivom Tekstilne tvornice a.d. ${ }^{28}$, sa zasebnim privremenim upraviteljima i zasebnim knjigovodstvom, ali sa zajedničkom blagajnom i zajedničkom administrativnom kancelarijom, te su stoga činile nerazdvojivu proizvodnu cjelinu. Isprepletenost zajedničke djelatnosti i poslovanja najbolje možemo prosuditi po Izvještaju o financijskom stanju tvornice Vuna d.d. na osnovi naloga DUND-a u Beogradu u kojem stoji da se veliki broj sirovina i pomoćnoga materijala za tvornicu Vuna d.d. proizvodi na industrijskim kolosijecima Tekstilnih tvornica d.d. uz pomoć posuđenih strojeva za proizvodnju Vune d.d. ${ }^{29}$ Poduzeće Tekstilne tvornice a.d. pod vodstvom koncerna obitelji Ilić nastalo je na temelju fuzije s Prvim hrvatskim mlinom na čigre d.d. u Karlovcu te se postupno stari mlin pretvara u poduzeće za trikotažu i štofanje. Karlovački kotarski sud na zahtjev stranke rješenjem od 3. srpnja 1929. određuje brisanje naziva poduzeća Prvi hrvatski mlin na čigre

25 HR-HDA-313-ZUND, kut. 447, Izvještaj o pregledu financijskog stanja tvornice Vuna d.d. na osnovu naloga Državne uprave narodnih dobara u Beogradu br. 14.492 od 12. rujna 1945.

26 HR-HDA-367-RZSSRH-19, Anketni obrazac Statističkog ureda pri Predsjedništvu NRH od 30. kolovoza 1945.

27 d.d. - dioničko društvo.

28 a.d. - akcionarsko društvo.

29 HR-HDA-313-ZUND, kut. 447, Izvještaj o pregledu financijskog stanja tvornice Vuna d.d. na osnovu naloga Državne uprave narodnih dobara u Beogradu br. 14.492 od 12. rujna 1945. 
d.d., Karlovac, iz trgovačkoga registra i upis novoga poduzeća pod nazivom Tekstilne industrije a.d. ${ }^{30}$

Od početka Drugoga svjetskog rata do 1944. poduzeće se bavilo proizvodnjom muškoga, ženskoga i dječjega donjeg rublja od pamuka, vune i svile te platna za radna odijela. Tvornica Tekstilne tvornice a.d. nalazila se na periferiji Karlovca, kraj rijeke Korane, na površini od 4516 m² $^{2}$ Ispred tvorničkoga kruga nalazile su se dvije livade površine od $84577 \mathrm{~m}^{2}$, koje su bile pravo bogatstvo za daljnje širenje tvorničkih objekata i proizvodne djelatnosti s obzirom na povoljan strateški položaj zbog blizine Korane, koja je omogućavala korištenje vodne energije u proizvodne svrhe. ${ }^{31}$

Ono što je činilo veliku prednost u odnosu na druga poduzeća jest to što je poduzeće Tekstilne tvornice a.d. imalo vlastiti električni pogon Francisove turbine od 290 konjskih snaga s pripadajućim instalacijama. ${ }^{32}$ Tekstilne tvornice a.d. 1938. postaju Tekstilne tvornice d.d. ${ }^{33}$

Kotarski sud u Karlovcu donio je odluku kojom se Vladi Iliću, vodećem dioničaru koncerna Ilić, zbog suradnje s ustaškim vlastima izriče mjera konfiskacije imovine. Nadalje, sud je donio rješenje po kojem se određuje da je konfiscirani dio imovine vezan za Tekstilne tvornice d.d. 12500 dionica u iznosu od 100 dinara po dionici te 22140 dionica koje su sastavni dio većinskoga dijela vlasništva vezano uz drugi dio koncerna Ilić, Vuna d.d., također u iznosu od 100 dinara po dionici. Zbog kaznenih djela iz članka 14. Uredbe o vojnim sudovima Vojni sud Komande grada Beograda osudio je industrijalca Vladu Ilića na konfiskaciju imovine prema razmjeru dionica kako je rečeno. Za provođenje konfiskacije ovlašćuje se Kotarski sud u Karlovcu, koji je na temelju presude Vojnoga suda analizirao vrijednosti dionica. U rješenju Kotarskoga suda Karlovac od 17. kolovoza 1945. stoji da je konfiscirano samo 3690 dionica Vune d.d. koje su pronađene prilikom popisa imovine u blagajni poduzeća. Ostatak u iznosu od 22860 dionica pohranjen je kod Jadransko-podunavske banke u Beogradu, 18450 dionica nalazi se kod Srpske banke u Zagrebu, a dionice poduzeća Tekstilne industrije d.d. nalaze se kod Vlade Ilića, čije je prebivalište u vrijeme konfiskacije bio Beograd. Zakonskom regulativom utvrđeno je da konfiskaciju imovine u obliku dionica koje posjeduje Vlada Ilić ima

\footnotetext{
30 HR-HDA-313-ZUND, kut. 447, Izvještaj o pregledu financijskog stanja tvornice Tekstilne tvornice a.d., Karlovac na osnovu naloga Državne uprave narodnih dobara u Beogradu br. 19.492 od 12. rujna 1945.

31 Isto.

32 Isto.

33 HR-HDA-313-ZUND, kut. 447, Izvještaj o pregledu financijskog stanja tvornice Tekstilne tvornice a.d., Karlovac na osnovu naloga Državne uprave narodnih dobara u Beogradu br. 19.492 od 12. rujna 1945., Dopis Tekstilne tvornice d.d. Okružnom narodnom odboru, Odjel za narodnu imovinu, Karlovac, upitnik od 29. kolovoza 1946.
} 
provesti, u smislu članka 16., kotarski sud na čijem se području nađe dotični većinski dioničar. ${ }^{34}$

Iz iskaza dioničara od 31. siječnja 1946., koji je u obliku zahtjeva upućen iz Državne uprave u Beogradu na adresu ZUND-a NR Hrvatske, vidljiv je popis dioničara poduzeća Vuna d.d. kako slijedi:

Tablica 1. Popis dioničara poduzeća Vuna d.d. od 31. siječnja $1946 .^{35}$

\begin{tabular}{|l|r|r|}
\hline Vlada Ilić & 22140 dionica & 100 dinara \\
\hline Kosta Ilić & 5 dionica & 100 dinara \\
\hline Uroš Ilić & 5 dionica & 100 dinara \\
\hline Siniša Ilić & 5 dionica & 100 dinara \\
\hline Milorad Naumović & 5 dionica & 100 dinara \\
\hline Petar Kostić & 5 dionica & 100 dinara \\
\hline Juraj Jendriš & 5 dionica & 100 dinara \\
\hline Branislav Stefanović & 5 dionica & 100 dinara \\
\hline $\begin{array}{l}\text { Tvornica vunenih tkanina Kosta Ilić i sinovi } \\
\text { a.d., Beograd }\end{array}$ & 22825 dionica & 100 dinara \\
\hline Ukupno & 45000 dionica & 100 dinara \\
\hline Dionička glavnica & 4.500 .000 dinara \\
\hline
\end{tabular}

Iskaz dioničara veoma je bitan jer je na temelju njega vidljivo koliko koji član koncerna Ilić participira u vlasništvu nad poduzećem Vuna d.d. te na temelju dioničkoga udjela DUND u Beogradu može procijeniti konfiscirani iznos predmetne imovine. U slučaju koji je naveden u obliku tabelarnoga iskaza vidljiv je udio dionica koncerna Ilić u poduzeću Vuna d.d. ${ }^{36}$

U pokušaju sprečavanja konfiskacije Vune d.d. uprava poduzeća poslala je Sekretarijatu DUND-a dopis iz kojega je vidljivo da je u ratnom razdoblju poduzeće bilo povojničeno, odnosno da je za potrebe vojske NDH bilo prisiljeno proizvoditi svu potrebnu opremu u okviru svojih proizvodnih mogućnosti. Nadalje, navodi se da su članovi Upravnoga i Nadzornoga odbora koji su se u

\footnotetext{
34 HR-HDA-313-ZUND, kut. 447, Rješenje Kotarskog narodnog suda u Karlovcu od 17. kolovoza 1945., broj II K-19/45.

35 HR-HDA-313-ZUND, kut. 447, Izrada autora prema podacima o iskazu dioničara od 31. siječnja 1946.

36 HR-HDA-313-ZUND, kut. 447, Dopis Državnoj upravi narodnih dobara broj II-4844/46. od 6. veljače 1946.
} 
ratu zatekli na teritoriju poslijeratne Federalne Hrvatske bili neskloni ustaškim vlastima te nisu davali nikakve novčane priloge na raspolaganje ustaškoj vojsci i ustanovama.

Članovi Upravnoga i Nadzornoga odbora u dopisu kazuju da su u više navrata davali novčana sredstva za stradale od ustaškoga terora te je novčano pomagana i „narodno oslobodilačka borba”. ${ }^{37}$

U nastavku teksta tabelarno ću prikazati račune dobiti i gubitka Vune d.d. od 25. srpnja 1945., koji će nam olakšati razumijevanje cjelokupne gospodarsko-političke situacije unutar koje se odvijala konfiskacija poduzeća kao moćna poluga obračuna s tzv. nenarodnim elementima optuženima za suradnju s ustaškim vlastima u ratnim vremenima.

Tablica 2. Račun aktive poduzeća Vuna d.d. 25. srpnja 1945. (u dinarima) ${ }^{38}$

\begin{tabular}{|l|r|}
\hline Novčani zavodi & $355.080,04$ \\
\hline Vrijednosni papiri & $10.906 .150,00$ \\
\hline Dužnici & $109.522,15$ \\
\hline Sirovine & $2.698 .525,00$ \\
\hline Pogonski materijal & $18.030,00$ \\
\hline Poluproizvodi & $2.142 .420,00$ \\
\hline Gotova roba & $886.952,65$ \\
\hline Zgrade & $5.168 .186,77$ \\
\hline Zemljište & $412.574,00$ \\
\hline Strojevi & $8.497 .041,28$ \\
\hline Uređaji za otpremu i prijevoz & $52.000,00$ \\
\hline Osobni i teretni automobili & $110.000,00$ \\
\hline Alati i namještaj & $62.219,23$ \\
\hline Račun kaucija i garancija & $27.807,24$ \\
\hline UKUPNO & $31.394 .508,36$ \\
\hline
\end{tabular}

37 HR-HDA-313-ZUND, kut. 447, Brzojav Upravnog odbora Vuna d.d. Sekretarijatu Državne uprave narodnih dobara od 28. siječnja 1946.

38 HR-HDA-313-ZUND, kut. 447, Izrada autora prema podacima računa dobiti i gubitka od 25. srpnja 1945. 
Tablica 3. Račun pasive poduzeća Vuna d.d. 25. srpnja 1945. (u dinarima) $)^{39}$

\begin{tabular}{|l|r|}
\hline Glavnica & $4.500 .000,00$ \\
\hline Zakonske rezerve & $1.206 .459,69$ \\
\hline Ostale rezerve & $83.315,50$ \\
\hline Rezerve za umanjenje aktivnih stavaka & $11.013 .649,88$ \\
\hline Ostala dugovanja & $6.385 .020,72$ \\
\hline UKUPNO & $23.188 .445,79$ \\
\hline
\end{tabular}

Ako kompariramo ukupne vrijednosti aktive i pasive iz računa dobiti i gubitka na dan 25. srpnja 1945., vidimo da je Vuna d.d. poslovala s dobitkom u iznosu ukupne vrijednosti od 8.206.062,57 dinara. Logika socijalističke revolucije o čijim sam postulatima obračuna s političkim neistomišljenicima pisao jasna je i neumoljiva.

Ideološki gledano, svako poduzeće koje je ratno vrijeme prošlo neokrznuto ratnim štetama i razaranjem te poslovalo s pozitivnom bilancom u očima nositelja socijalističke revolucije poticalo je sumnju na održavanje prijateljskih i poslovnih odnosa s ustaškim vlastima.

U prilog rečenom prikazat ću tablicu iz koje će prema iskazu stanja prometa od 1941. do 1945. biti vidljivo poslovanje poduzeća Vuna d.d. u četverogodišnjem ratnom razdoblju.

Tablica 4. Iskaz stanja vrijednosti prometa robe poduzeća Vuna d.d. prodane trgovcima i državnim ustanovama od 1941. do 1945. (u dinarima) $)^{40}$

\begin{tabular}{|l|r|r|r|}
\hline \multicolumn{1}{|c|}{ Godina } & $\begin{array}{c}\text { Vrijednost prometa } \\
\text { robe prodane } \\
\text { trgovcima }\end{array}$ & $\begin{array}{c}\text { Vrijednost prometa } \\
\text { robe prodane državnim } \\
\text { ustanovama }\end{array}$ & UKUPNO \\
\hline 1941. & $7.950 .908,50$ & $6.438 .782,70$ & $14.389 .691,20$ \\
\hline 1942. & $2.641 .581,90$ & $64.844 .113,50$ & $67.485 .695,40$ \\
\hline 1943. & $766.971,00$ & $57.888 .608,00$ & $58.655 .579,00$ \\
\hline 1944. & $1.160 .881,17$ & $150.771 .584,08$ & $151.932 .465,25$ \\
\hline 1945. & $2.289 .397,50$ & $63.415 .124,40$ & $65.704 .521,90$ \\
\hline UKUPNO & $14.809 .740,07$ & $343.358 .212,68$ & $358.167 .952,75$ \\
\hline
\end{tabular}

39 Isto.

40 HR-HDA-313-ZUND, kut. 447, Izrada autora prema podacima iskaza prometa od 1941. do 1945. od 28. siječnja 1946. 
U prethodnom tabelarnom prikazu imamo priliku vidjeti ono što je, pretpostavlja se, izazvalo najveću sumnju novouspostavljene vlasti u suradnju koncerna Ilić i njihovih poslovnih akvizicija s ustaškim vlastima. Na početku rata prodano je više robe trgovcima nego državnim ustanovama. Slijedom ratnih previranja i dolaska ustaša na vlast poslovanje koncerna poprima velike razlike u odnosu na početnu godinu rata na ovim prostorima. Od 1942. do 1945. vrijednost robe prodane državnim vlastima premašuje vrijednost robe prodane trgovcima, s tim da valja naglasiti da je najveća razlika bila 1944. i iznosila je $150.771 .584,08$ dinara od robe prodane državnim ustanovama naspram neznatnih 1.160.881,17 dinara od robe prodane trgovcima.

Jednostavan pogled na iskaze dioničara, račune dobiti i gubitka te nerazmjer iskaza platnoga prometa u pitanju razlika u vrijednosti robe prodane državnim ustanovama i malim trgovcima za vrijeme rata, bez obzira na to je li koncern poslovao svojevoljno ili ga je prisilila ustaška vlast, novoustrojenoj je vlasti bio više nego dovoljan razlog da se po Vojnom sudu Komande grada Beograda 25. ožujka 1945. donese odluka kojom se vlasniku koncerna Vladi Iliću konfiscira cjelokupna imovina čiju je vrijednost ustanovio Kotarski sud u Karlovcu. ${ }^{41}$

\section{Tvornica marama d.d.}

Tvornica marama d.d. osnovana je 31. ožujka 1933. u Karlovcu. Dozvolu za rad izdalo je načelništvo u Karlovcu odlukom od 3. listopada 1933. godine. Glavna djelatnost poduzeća odnosila se na proizvodnju džepnih maramica i marama za glavu, za čije je potrebe proizvodnje, u smislu oplemenjivanja proizvoda, koristila usluge drugih poduzeća. ${ }^{42}$

Odlukom načelništva u Karlovcu od 24. travnja 1933. poduzeće je oslobođeno plaćanja gradskih nameta i uvoznine za građevni materijal i strojeve za potrebe normalne tvorničke proizvodnje tijekom deset godina počevši od 1933., odnosno godine osnutka, te će u idućem periodu poduzeće pokušati ostvariti maksimalni proizvodni učinak. ${ }^{43}$

Tvornicu marama d.d. konfiscirala je NDH na temelju Zakonske odredbe o podržavljenju imetka Židova i židovskih poduzeća od 9. listopada 1941., Zakonske odredbe o ukidanju Državnog ravnateljstva za ponovu i Državnog ravnateljstva za prehranu od 30. prosinca 1941. i propisa Naredbe o podjeli poslova ukinutog Državnog ravnateljstva za ponovu i Državnog ravnateljstva

\footnotetext{
41 HR-HDA-313-ZUND, kut. 447, Rješenje Kotarskog suda u Karlovcu od 17. kolovoza 1945. broj II K-19/45.

42 HR-HDA-367-RZSSRH-19, Osnovni podaci o poduzeću.

43 HR-HDA-367-RZSSRH-19, Povremeni podaci tvornice Marama d.d. broj 02423.
} 
za prehranu od 14. siječnja 1942. godine. Ured za podržavljeni imetak Odjela za državnu imovinu, navjeru i dugove Državne riznice NDH podržavljuje u korist NDH bez naknade prethodno opisani imetak u vlasništvu Ede Čange.

U opisu podržavljenoga imetka, kako će biti opisano u tablici, Židov Edo Čango raspolagao je s ukupno 200 dionica vlasništva kojima će upravljati Državna riznica te Odjel za državnu imovinu, navjeru i dugove, odnosno Ured za podržavljeni imetak. ${ }^{44}$

Dopisom Ministarstva državne riznice NDH, Odjela za državnu imovinu, navjeru i dugove te Ureda za podržavljeni imetak Ministarstvu narodnog gospodarstva, Glavnom ravnateljstvu za obrt, veleobrt i trgovinu, Odjelu za gospodarstvenu politiku, pozivanjem na članak 2. Naredbe sa zakonskom snagom o otuđivanju i poslovanju privrednih poduzeća od 30. listopada 1940. broj 63401-VII-1940., potpisani Ured za podržavljeni imetak prijavljuje kao predstavnik NDH vlasništvo od 400 dionica Tvornice marama d.d.

Od toga je 200 dionica prijašnjega vlasništva Ede Čange iz Karlovca stečeno odlukom o podržavljenju od 23. rujna 1941., a prijašnje vlasništvo Ludwiga i Fritza Baumla (190 dionica) i Otta Baumla (10 dionica) iz Karlovca na temelju Zakonske odredbe o podržavljenju židovske imovine od 30. listopada 1942. godine. Prijavljene dionice vode se pod brojevima 0201-400 i 0601-800. ${ }^{45}$

Radi što boljega uvida u poslovanje poduzeća, prije svega izvoznu djelatnost, donosim tabelarni prikaz prodaje od ukupne količine proizvodnje na dan 4. lipnja 1941. koji je Tvornica marama d.d. poslala na adresu Ministarstva narodnog gospodarstva NDH, Odjela za obrt, industriju i trgovinu pod rednim brojem 359/1941.

Tablica 5. Prikaz prodaje od ukupne količine proizvodnje poduzeća Tvornica marama d.d. po područjima izvoza na dan 4. lipnja $1941 .{ }^{46}$

\begin{tabular}{|l|r|r|}
\hline Područje izvoza & Vrijednost u dinarima & Vrijednost ( \%) \\
\hline NDH & $2.791 .290,20$ & 45,94 \\
\hline Vojvodina & $759.799,85$ & 12,60 \\
\hline Srbija i Makedonija & $1.057 .598,50$ & 17,36 \\
\hline Slovenija & $1.093 .118,85$ & 18,00 \\
\hline Ostala područja bivše Jugoslavije & $371.906,50$ & 6,10 \\
\hline
\end{tabular}

44 HR-HDA-313-ZUND, kut. 448, Odluka državne riznice, Odjel za državnu imovinu, navjeru i dugove - Ured za podržavljeni imetak od 29. rujna 1941.

45 HR-HDA-313-ZUND, kut. 448, Prijava dionica Tvornice marama d.d. radi upisa u upisnik od strane Ministarstva državne rizinice Nezavisne Države Hrvatske, Odjela za državnu imovinu, navjeru i dugove, Ured za podržavljeni imetak Ministarstvu narodnog gospodarstva, Glavno ravnateljstvo za obrt, veleobrt i trgovinu, Odjel za gospodarstvenu politiku od 22. ožujka 1943.

46 HR-HDA-367-RZSSRH-19, Izrada autora prema podacima upitnoga obrasca Ministarstva narodnog gospodarstva, Odjela za obrt, industriju i trgovinu od 4. lipnja 1941. 
Ako analiziramo podatke iz tablice, možemo zaključiti da je većinski postotak izvozne djelatnosti Tvornice marama d.d. bio plasiran na teritorij tada novostvorene $\mathrm{NDH}$, što će već samo po sebi, kako smo imali priliku vidjeti u prethodnom slučaju, biti dovoljan povod za sumnju u poslovnu i prijateljsku suradnju s ustaškim vlastima.

Iz dopisa Tvornice marama d.d. Državnom ravnateljstvu za gospodarsko knjigovodstvo od 24. rujna 1941. kao prilog upitnom popisu od 11. rujna 1941. nalaze se imena i prezimena svih dioničara podijeljenih prema mjestu držanja dionica.

Tablica 6. Dioničari Tvornice marama d.d. 24. rujna $1941 .^{47}$

\begin{tabular}{|l|r|}
\hline Đuro Mužinić & 200 dionica vlasništva \\
\hline Otto Bauml & 10 dionica vlasništva \\
\hline Fritz Bauml & 95 dionica vlasništva \\
\hline Ludwig Bauml & 95 dionica vlasništva \\
\hline Mirko Malović & 95 dionica vlasništva \\
\hline
\end{tabular}

Nadalje, kod Prve hrvatske štedionice, podružnica Karlovac, nalazi se popis sljedećih dioničara:

Tablica 7. Popis dioničara Tvornice marama d.d. kod Prve hrvatske štedionice, podružnica Karlovac, 24. rujna 1941 . $^{48}$

\begin{tabular}{|l|r|}
\hline Mirko Malović & 105 dionica vlasništva \\
\hline Milan Lacković & 200 dionica vlasništva \\
\hline Ivan Blažeković & 150 dionica vlasništva \\
\hline Stjepan Magdić & 100 dionica vlasništva \\
\hline Zora Jovanović & 150 dionica vlasništva \\
\hline Bogdan Novković & 100 dionica vlasništva \\
\hline Edo Čango & 200 dionica vlasništva \\
\hline
\end{tabular}

Uime Kotarskoga suda u Karlovcu pod predsjedanjem predsjednika sudskoga vijeća Eugena Špoljarića sastavljen je zapisnik u prostorijama Tvornice

47 HR-HDA-367-RZSSRH-19, Izrada autora prema podacima Tvornice marama d.d. upućenim Državnom ravnateljstvu za gospodarsko knjigovodstvo od 24. rujna 1941.

48 Isto. 
marama d.d., Tuškanova ulica $2 \mathrm{u}$ Karlovcu, iz kojega je vidljiv popis stvarnoga stanja imovine koja se ima konfiscirati u doglednom razdoblju. Zapisnik sastavljen 24. studenog 1945. poslužit će kao predložak i pravna osnova za daljnji postupak konfiskacije cjelokupne imovine Tvornice marama d.d. ${ }^{49} \mathrm{Na}$ temelju navedene odluke popisani su predmeti koji su pronađeni u Tvornici marama d.d. Najvažnije je ono što navodi sudski vještak Josip Mrgan, a to je da su prema posljednjem zapisniku sastanka Glavne skupštine održanog u kolovozu 1941. vlasnici dionica bili kako slijedi u tabelarnom prikazu:

Tablica 8. Vlasnici dionica poduzeća Tvornica marama d.d. prema posljednjem zapisniku sastanka Glavne skupštine $1941 .{ }^{50}$

\begin{tabular}{|l|r|}
\hline Đuro Mužinić & 200 dionica vlasništva \\
\hline Ivan Blažeković & 150 dionica vlasništva \\
\hline Milan Lacković & 200 dionica vlasništva \\
\hline Ludwig i Fritz Bauml & 190 dionica vlasništva \\
\hline Bogdan Novković & 100 dionica vlasništva \\
\hline Edo Čango & 200 dionica vlasništva \\
\hline Otto Bauml & 10 dionica vlasništva \\
\hline Mirko Malović & 150 dionica vlasništva \\
\hline
\end{tabular}

Analizom tablica i dostupne dokumentacije te pozivanjem na izloženo u smislu konfiskacije dionica ustaških vlasti možemo primijetiti da se sadržaj spomenutih dionica izmijenio nakon svršetka rata jer je prijašnja vlast NDH podržavila dionice Ludwiga i Fritza Baumla te Otta Baumla i Ede Čange, koje su zajed no činile 400 dionica vlasničkoga udjela. Podržavljenih 400 dionica preuzela je svojedobno Državna riznica NDH, a većina ostalih dionica nalazila se u obliku pologa deponiranih u Prvoj hrvatskoj štedionici, podružnica Karlovac. $^{51}$

Zaključno, Kotarski sud u Karlovcu rješenjem od 22. siječnja 1946. odlučuje o konfiskaciji cjelokupne imovine poduzeća Tvornica marama d.d. U daljnjem obrazloženju kaže se da postupku konfiskacije podliježu nekretnine Tvornice marama d.d. upisane u nadležnosti Kotarskoga odbora Švarča. Prema rješenju, ukupna vrijednost nekretnina, zemljišta i tvorničkih postrojenja

49 HR-HDA-313-ZUND, kut. 448, Zapisnik Kotarskog suda u Karlovcu od 24. studenog 1945.

50 HR-HDA-313-ZUND, kut. 448, Izrada autora prema Zapisniku sastavljenom uime Kotarskog narodnog suda u Karlovcu od 24. studenog 1945.

51 HR-HDA-313-ZUND, kut. 448, Zapisnik Kotarskog suda u Karlovcu od 24. studenog 1945. 
iznosi 2.791.332 dinara. ${ }^{52}$ Konfiscira se u korist države i sva oprema za proizvodnju, strojevi, pomoćni materijal za strojeve, „sirova” i „gotova” roba za čije se utvrđivanje vrijednosti kao pravna osnova koristio spomenuti zapisnik sastavljen u prostorijama Tvornice marama d.d. 24. studenog 1945. godine. Konfiscirana pokretna imovina predana je po sudskom izaslaniku na čuvanje privremenom upravitelju Boži Kovačeviću, koga je postavio Okružni narodni odbor, Odjel za industriju u Karlovcu. U nastavku teksta tabelarno ću prikazati pojedinačne vrijednosti sredstava za proizvodnju.

Tablica 9. Vrijednost sredstava za proizvodnju prema zapisniku od 22. siječnja 1946. (u dinarima) $)^{53}$

\begin{tabular}{|l|r|}
\hline Strojevi & $1.105 .200,00$ \\
\hline Namještaj & $94.970,00$ \\
\hline Pomoćni materijal za strojeve & $84.500,00$ \\
\hline Sirova roba & $371.988,00$ \\
\hline Gotova roba & $202.256,80$ \\
\hline Razni predmeti & $50.655,00$ \\
\hline UKUPNO & $1.909 .569,80$ \\
\hline
\end{tabular}

Konfiscirana Tvornica marama d.d. rješenjem Kotarskoga suda prenosi se u nadležnost i na upravljanje Okružnoj upravi narodnih dobara u Karlovcu. ${ }^{54}$

Domaća tvornica predenja i tkanja pamuka d.d., Duga Resa (Mira, tvornica čarapa d.d., Karlovačka tvornica popluna d.d.)

Poduzeće Domaća tvornica predenja i tkanja pamuka d.d. osnovana je 1884. sa sjedištem u Dugoj Resi, gradu udaljenom $10 \mathrm{~km}$ od Karlovca. U upitniku za firmu i tvornička postrojenja upućenom poduzeću iz Statističkoga ureda pri Predsjedništvu NR Hrvatske od 4. rujna 1945. kao najvažnije djelatnosti navode se proizvodnja pamuka i miješanoga prediva, a kao temeljne sirovine za njihovu proizvodnju koriste se pamuk, celulozna vata i kudjelja. ${ }^{55}$

52 HR-HDA-313-ZUND, kut. 448, Zapisnik Kotarskog suda u Karlovcu od 22. siječnja 1946.

53 HR-HDA-313-ZUND, kut. 448, Izrada autora prema Zapisniku Kotarskog suda u Karlovcu od 22. siječnja 1946.

54 HR-HDA-313-ZUND, kut. 448, Zapisnik Kotarskog suda u Karlovcu od 22. siječnja 1946.

55 HR-HDA-367-RZSSRH-19, Upitnica za firmu i tvornička postrojenja Statističkog ureda pri Predsjedništvu NR Hrvatske od 4. rujna 1945. 
Poduzeće je raspolagalo, u smislu proizvodne djelatnosti, predionicom i tkaonicom pamuka, objektima za proizvodnju vate, bojadisaonicom i bjelionicom. ${ }^{56}$ Iznimno je bitno reći i da je prema anketnom obrascu Statističkoga ureda pri Predsjedništvu Narodne vlade Hrvatske vidljivo da Domaćoj tvornici predenja i tkanja pamuka d.d. pripadaju Mira, tvornica čarapa d.d. sa sjedištem u Dugoj Resi, te Karlovačka tvornica popluna d.d. sa sjedištem u Karlovcu na adresi Gaza broj 18. Nadalje, iz anketnoga obrasca vidljivo je da je Domaća tvornica predenja i tkanja pamuka d.d. jedini vlasnik Mire d.d. s posjedovanjem svih 5000 dionica te vlasnik Karlovačke tvornice popluna d.d. s posjedovanjem svih 12489 dionica. ${ }^{57} \mathrm{U}$ nastavku ćemo vidjeti da je povezanost $\mathrm{i}$ isprepletenost tih poduzeća vlasničkim udjelima bitna jer je odluka o konfiskaciji triju poduzeća bila obuhvaćena jednim rješenjem Kotarskoga narodnog suda u Karlovcu.

Kad povučemo analogiju s Tvornicom marama d.d., vidjet ćemo, prema obradi dostupne dokumentacije, da su Domaću tvornicu predenja i tkanja pamuka d.d. te Karlovačku tvornicu popluna d.d., koja vlasničkom strukturom potpada pod ingerenciju Domaće tvornice predenja i tkanja pamuka d.d., podržavile i vlasti NDH i poslijeratne komunističke vlasti.

U tom smislu možemo razmotriti odluku Ministarstva državne riznice, Odjela za državnu imovinu, navjeru i dugove te Ureda za podržavljeni imetak koja je u smislu propisa 7. zakonske odredbe o podržavljenju židovske imovine od 30. listopada omogućila poništavanje ukupno 2274 dionice Domaće tvornice za predenje i tkanje pamuka d.d. koje su bile u vlasništvu Lise Haas. Kako toliki broj dionica nije predan na upravljanje u unaprijed određenom razdoblju Ministarstvu državne riznice, Odjelu za državnu imovinu, navjeru i dugove, odnosno Uredu za podržavljeni imetak, „isti se broj ukupnih vrijednosti dionica od izdatnika dionica ima predati na upravljanje Ministarstvu državne riznice te će to novo izdanje dionica biti oslobođeno samoupravnih i državnih pristojba svih vrsta". ${ }^{58}$

Odluka Ministarstva državne riznice pravno uporište ima u odluci toga ministarstva u kojoj se na temelju 1. zakonske odredbe o podržavljenju imetka Židova i židovskih poduzeća od 2. listopada 1941., 2. zakonske odredbe o ukidanju Državnog ravnateljstva za ponovu i Državnog ravnateljstva za prehranu od 30. prosinca 1941. i propisa Naredbe o podjeli poslova ukinutog Državnog ravnateljstva za ponovu te Državnog ravnateljstva za prehranu od 14. siječnja

\footnotetext{
56 HR-HDA-313-ZUND, kut. 433, Opći podaci o poduzeću broj 798.

57 HR-HDA-367-RZSSRH-19, Anketni dio obrasca Statističkog ureda pri Predsjedništvu NR Hrvatske od 4. rujna 1945.

58 HR-HDA-313-ZUND, kut. 433, Odluka Ministarstva državne riznice, Odjela za državnu imovinu, navjeru i dugove, Ureda za podržavljeni imetak broj 23228-D-1943. od 17. travnja 1943.
} 
1942. decidirano izjavljuje da se ima provesti podržavljenje opisanoga vlasničkoga židovskog imetka bez naknade u iznosu od 2274 dionice Domaće tvornice predenja i tkanja pamuka d.d. koje su u vlasništvu Lise Haas. ${ }^{59}$

Identične zakonske osnove, u malo modificiranom obliku, na temelju Zakona o podržavljenju židovske imovine od 30. listopada 1942. korištene su i u primjeru Tvornice popluna d.d. 1943., kako ću pokazati u nastavku. Naime, 21. travnja 1943. Ministarstvo državne riznice, Odjel za državnu imovinu, navjeru i dugove te Ured za podržavljeni imetak donose odluku kojom se poništava imetak u iznosu od 275 dionica poduzeća Tvornica popluna d.d. koje su bile u vlasništvu Jelke Reiner te se oduzima 500 dionica poduzeća koje su bile u vlasništvu Otona Weissa, odnosno 75 dionica poduzeća vlasnika Alberta Ofnera iz Karlovca. ${ }^{60}$ Rješenjem Ministarstva državne riznice NDH od 7. svibnja 1943. donosi se odluka o podržavljenju 550 dionica koje su bile vlasništvo Antuna Goldschmidta iz Zagreba. ${ }^{61}$

Nešto kasnije, u studenom 1942., Sudbeni stol kao trgovački sud na sjednici pod predsjedanjem Stjepana Konjikovića is vijećnicima Sudbenoga stola Antunom Sakijem i Ivanom Kasumovićem u smislu prethodno navedenih zakonskih propisa NDH također donosi zaključak o podržavljenju 2274 dionice u vlasništvu Lise Haas, koje se imaju predati na raspolaganje Ministarstvu državne riznice NDH. Nadalje, Sudbeni stol utvrđuje da se određuje brisanje dotadašnjega člana Ravnateljstva poduzeća dr. Davida Karlovića iz Zagreba. ${ }^{62}$

Informacije o tijeku i uspješnosti poslovanja razaznajemo iz dosjea općih podataka poduzeća koji se vodio pri Zemaljskoj komisiji za utvrđivanje zločina okupatora i njihovih pomagača, gdje je vidljivo da je dionička glavnica poduzeća iznosila 56.250.000 dinara, a podijeljena je na 22500 dionica po 2.500 dinara. $^{63}$

Valja naglasiti da je većina kapitala u okviru dioničke glavnice bila inozemnoga podrijetla. Dioničari su prikazani tabelarno u nastavku.

\footnotetext{
59 HR-HDA-313-ZUND, kut. 433, Odluka o podržavljenju Ministarstva državne riznice, Odjela za državnu imovinu, navjeru i dugove, Ureda za podržavljeni imetak broj P.2765. od 7. rujna 1942.

60 HR-HDA-313-ZUND, kut. 438, Odluka Ministarstva državne riznice, Odjela za državnu imovinu, navjeru i dugove, Ureda za podržavljeni imetak broj 22706-D-1943. od 21. travnja 1943. ${ }_{61}$ HR-HDA-313-ZUND, kut. 438, Odluka Ministarstva državne riznice, Odjela za državnu imovinu, navjeru i dugove, Ureda za podržavljeni imetak broj 24579-D-1943. od 7. svibnja 1943.

62 HR-HDA-313-ZUND, kut. 433, Zaključak Sudbenog stola od 27. studenog 1942., Poslovni broj VI. Fi. 10/39-53.

${ }_{63}$ HR-HDA-313-ZUND, kut. 433, Dosje općih podataka poduzeća koji se vodio kod Zemaljske komisije za utvrđivanje zločina okupatora i njihovih pomagača pod brojem 2677/45., 1945.
} 
Tablica 10. Popis dioničara prema dosjeima općih podataka Domaće tvornice predenja i tkanja pamuka d.d. iz $1945 .^{64}$

\begin{tabular}{|l|r|}
\hline \multicolumn{1}{|c|}{ DIONIČARI } & BROJ DIONICA \\
\hline Etexco A.G. Zurich & 7500 \\
\hline dr. Fritz Kind, Zurich & 937 \\
\hline $\begin{array}{l}\text { dr. Felix Haas, Duga Resa (kao Židova, } \\
\text { Nijemci su ga odveli u logor) }\end{array}$ & 2274 \\
\hline Edwin Binder, New York & 6228 \\
\hline Mary Burnsid & 3102 \\
\hline M. Palm, New York & 250 \\
\hline Florence Marion, New York & 1212 \\
\hline Franjo pl. Seemann, Rio de Janeiro & 997 \\
\hline UKUPNO & 22500 \\
\hline
\end{tabular}

U dokumentu dalje stoji da je za vrijeme okupacije proizvodnja u poduzeću naglo pala uslijed nestašice sirovina uzrokovane ratnim neprilikama - na $10 \%$ predratne razine. Tijekom 1942. poduzeće je nabavljalo njemačke, talijanske i turske sirovine potrebne za izradu proizvoda, čime se ukupna količina proizvedenih dobara uspijeva vratiti na predratne razine, a taj se trend nastavlja i 1943. pa sve do listopada 1944., kada naglo pada na $5 \%$ predratne razine proizvodnje. Nadalje se kaže da je bilanca u cjelokupnom razdoblju bila u fazi rasta. ${ }^{65}$

Zemaljska komisija za utvrđivanje zločina okupatora i njihovih pomagača dalje utvrđuje da je proizvodnja tvornice u cijelom razdoblju ustaške vlasti bila prilagođena potrebama ustaške vojske i sličnih ustanova, pa količina proizvodnje doseže maksimalne učinke, odnosno prijeratne razine proizvodnje. Švicarski članovi Ravnateljstva tvornice, dr. Fritz Kind i Kristian Friedrich Fopp, tijekom ustaške vlasti postavili su na položaje stručnih namještenika poduzeća povjerenike potpuno odane postojećoj političkoj strukturi, a povremeni dolasci u tvornicu za vrijeme ustaške vlasti da bi dali upute za daljnji rad mogu se protumačiti fingiranjem stvarnoga članstva u Ravnateljstvu da bi se preko u ratu neutralne Švicarske jednostavnije nabavljale sirovine potrebne za

64 HR-HDA-313-ZUND, kut. 433, Izrada autora prema dosjeu općih podataka poduzeća koji se vodio kod Zemaljske komisije za utvrđivanje zločina okupatora i njihovih pomagača pod brojem 2677/45., 1945.

65 HR-HDA-313-ZUND, kut. 433, Dosje općih podataka poduzeća koji se vodio kod Zemaljske komisije za utvrđivanje zločina okupatora i njihovih pomagača pod brojem 2677/45., 1945. 
proizvodnju gotovih proizvoda. Temeljni zadaci povjerenika postavljenih na funkcije stručnih namještenika poduzeća bili su nabava sirovina, dispozicija odnosno otpremništvo, evidencija, nadzor nad tehničkim uređajima tvornice i osobljem te nadzor nad knjigovodstvom i financijskim poslovanjem poduzeća. ${ }^{66} \mathrm{Na}$ kraju dokumenta konstatira se da je trud koji je tvornica ulagala da održi i poveća predratne razine proizvodnje dovoljan pokazatelj suradnje s ustaškom vlasti te da pad proizvodnje krajem rata nije uvjetovan lošim načinom poslovanja i negativnim odnosom spram ustaške vlasti, nego ratnim neprilikama, prekinutim prometnim vezama i pomanjkanjem sirovina. ${ }^{67}$

Kotarski narodni sud u Karlovcu pod predsjedanjem Eugena Špoljarića, uz sudjelovanje narodnih sudaca Dragutina Andraševića i Tomislava Tonića, u predmetu konfiskacije imovine dioničkoga društva Domaća tvornica predenja i tkanja pamuka u Dugoj Resi, a nakon pregleda popisa imovine i zapisnika svojega izaslanika, donio je 21. veljače 1946. rješenje kojim se konfisciraju u korist države nekretnine Domaće tvornice predenja i tkanja pamuka d.d. Nekretnine koje su potpadale pod vlasništvo tvornice upisane su u gruntovne listove kotarskih okruga Duga Resa, Mrežnički Novaki i Mrzlo Polje Mrežničko. ${ }^{68}$ Konfiscirane nekretnine u vlasništvu Domaće tvornice predenja i tkanja pamuka d.d. predaju se i prenose na ime i vlasništvo FNRJ. Što se tiče spomenutih nekretnina koje prelaze u vlasništvo države, one su sljedeće: predionica, tkaonica, bojadisaonica, radničke stambene zgrade kolokvijalno nazvane „zgrade na otoku”, činovničke zgrade i dječji vrtić, objekti u šetalištu, kasino i restauracije, radničke zgrade, žandarmerijska vojarna, stambene zgrade u mjestu te industrijski kolosijeci. ${ }^{69}$ Kao što sam prije iznio, poduzeća u vlasništvu Domaće tvornice predenja i tkanja pamuka također su obuhvaćena rješenjem Kotarskoga narodnog suda u Karlovcu od 21. veljače 1946. na temelju kojega se ima provesti konfiskacija. Tako u istom rješenju stoji da se u korist države konfiscira cjelokupna imovina Mire, tvornice čarapa d.d. u Dugoj Resi u vlasništvu Domaće tvornice predenja i tkanja pamuka d.d., i to sav namještaj, strojevi, gotova roba, gotovina u iznosu od 5.533,17 dinara koja se nalazi deponirana u novčanim zavodima, mjenice u iznosu od 91.000 dinara, razna potraživanja u iznosu od 631.565,30 dinara te potraživanja u stranoj valuti u iznosu od 153.836,50 dinara. Naposljetku, u korist države konfiscira se i prenosi u vlasništvo države 5000 dionica poduzeća Mira, tvornica čarapa d.d. koje se nalaze u pologu u Hrvatskoj zemaljskoj banci d.d. u Zagrebu. ${ }^{70}$

66 Isto.

67 Isto.

68 HR-HDA-313-ZUND, kut. 433, Rješenje Kotarskog narodnog suda u Karlovcu broj II K. 501/45. od 21. veljače 1946.

69 Isto.

70 Isto. 
Što se pak tiče Karlovačke tvornice popluna d.d., istim rješenjem konfiscira se i u vlasništvo novoustrojene vlasti i države prenosi 9175 dionica koje su se nalazile u pologu u Hrvatskoj zemaljskoj banci d.d. u Zagrebu te 3314 dionica iste tvornice koje su se nalazile u blagajni Domaće tvornice predenja i tkanja pamuka d.d.

Nadalje, konfiscira se i u vlasništvo države prenosi imovina Domaće tvornice predenja i tkanja pamuka d.d. koju ona ima u obliku 12489 dionica vlasničkoga udjela u Karlovačkoj tvornici popluna d.d. ${ }^{71}$ Konfiskacija se provodi i nad nekretninama Karlovačke tvornice popluna d.d. u Karlovcu, koje su procijenjene na vrijednost od 1.596 .650 dinara, te pokretna imovina u obliku sirovina, polufabrikanata, kratke robe, gotovih popluna, inventara, namještaja i alata u vrijednosti od 1.656.329 dinara. Ista je popisana imovina i pripadajuća vrijednost utvrđena u zapisniku od 19. prosinca 1945. godine. ${ }^{72}$ Kraj rješenja donosi obrazloženje u kojem se Kotarski narodni sud u Karlovcu poziva na rješenja Okružnoga suda u Karlovcu od 20. studenog 1945. te potvrđenu presudu Vrhovnoga suda Hrvatske u Zagrebu od 20. studenog 1945., na temelju kojih su donesene odluke o konfiskaciji spomenutih poduzeća. Na temelju navedenih rješenja, koja su služila kao zakonska osnova za provedbu konfiskacije, utvrđene su sljedeće vrijednosti: u trenutku konfiskacije odnos aktive i pasive Domaće tvornice predenja i tkanja pamuka d.d. bio je 438.080.037,44 dinara aktive naspram 60.483.886,91 dinara pasive prema stanju računovodstvenih knjiga. Valja naglasiti da je u izračun, razmjerno iznosu vlasništva dionica većinskoga vlasništva od 12489 dionica koje Domaća tvornica predenja i tkanja pamuka d.d. ima, bila uključena i Karlovačka tvornica popluna d.d. U trenutku konfiskacije dionička glavnica iznosila je 56.250 .000 dinara, pričuve su iznosile 601.014.379,61 dinara, a prijelazne stavke 4.561.880 dinara. Takvo stanje ustanovljeno je pregledom popisa imovine iz tvorničkih knjiga. ${ }^{73}$

Posljednje poduzeće u većinskom vlasništvu Domaće tvornice predenja i tkanja pamuka d.d. - Mira, tvornica čarapa d.d., u trenutku konfiskacije imala je ukupnu aktivu u iznosu od 3.552.631,64 dinara naspram 625.862,15 dinara pasive. Dionička glavnica Mire, tvornice čarapa d.d. iznosila je 500.000 dinara, a pričuve $7.885 .013,67$ dinara. $^{74}$

Odnos iznosa aktive i pasive, iznosi dioničkih glavnica te pričuva i prijelaznih sredstava tvornica obrađenih u ovom dijelu rada, u smislu konfiskacije, jasan su nam pokazatelj uspješnosti poslovanja koja je u očima novouspostavljene vlasti bila sumnjiva u pogledu suradnje s ustaškim vlastima i otkupa

$\begin{array}{ll}{ }_{71} & \text { Isto. } \\ { }_{72} & \text { Isto. } \\ 73 & \text { Isto. } \\ { }_{74} & \text { Isto. }\end{array}$


proizvoda ustaške vojske i ostalih ustaških institucija, te su na temelju toga donesene odluke kojima se vlasništvo nad tvornicama i cjelokupnom pokretnom i nepokretnom imovinom prenosi u korist FNRJ.

Velebit, tvornica trikotaže i pletene robe d.d., Karlovac

Poduzeće Velebit, tvornica trikotaže i pletene robe d.d., Karlovac, prema upitniku za firmu Statističkoga ureda NR Hrvatske osnovana je 1927. u Donjoj Lendavi u Sloveniji. Poduzeće se 1939. seli u Karlovac zbog mjera olakšice razvoja industrije koje su poduzele lokalne vlasti (npr. davanje besplatnoga zemljišta i manji nameti da se potakne proizvodna djelatnost na području Karlovca). Poduzeće se prije nazivalo Blau i Bertoš pletiona, Karlovac. ${ }^{75}$ Osnovu proizvodne djelatnosti Velebita činila je proizvodnja ženskih i dječjih pulovera i prsluka, muških i dječjih košulja, muških i ženskih kupaćih kostima, za čiju su se proizvodnju koristile sirovine poput pamučnoga i vunenoga prediva te umjetna svila. ${ }^{76}$

Radi lakšega razumijevanja slučaja podržavljenja vezanog uz poduzeće Velebit potrebno je objasniti sekvestraciju kao poseban oblik podržavljenja. Sekvestracija je bila obuhvaćena Odlukom o prijelazu u državno vlasništvo neprijateljske imovine, o državnoj upravi nad imovinom neprisutnih lica i o sekvestru nad imovinom koju su ustaške vlasti prisilno otuđile od 21. studenog 1944. te se u Hrvatskoj tumačila Uputstvom za rad u vezi sa stavljanjem prijedloga za privremeni prijelaz neprijateljske imovine pod upravu i nadzor Državne uprave narodnih dobara. ${ }^{77}$

Do 1941. vlasnici poduzeća bili su Židovi Hinko Blau, Ljudevit Blau i Eugen Bartoš, pa je kao takvo 1942. pod prisilom prodano ustašama Josipu Tomljenoviću i Mati Serdaru u kunskoj valuti. ${ }^{78}$

Iz dopisa koji je ZUND NR Hrvatske uputio Ministarstvu industrije i rudarstva, Odjelu za tekstil i trikotažu, vidljivo je da su za vrijeme ustaške vlasti tvornički strojevi za endlanje te dva štrikaća stroja bili posuđeni na korištenje vlasnicima tvornice Uskok u Zemunu, odakle su preseljeni u Zagreb. ${ }^{79}$

\footnotetext{
75 HR-HDA-367-RZSSRH-19, Upitnica za firmu Statističkog ureda pri Predsjedništvu NR Hrvatske od 31. kolovoza 1945.

76 HR-HDA-367-RZSSRH-19, Upitnica za tvornice i rudnike Statističkog ureda pri Predsjedništvu NR Hrvatske od 28. kolovoza 1945.

77 RADELIĆ, Hrvatska u Jugoslaviji 1945. - 1991., 180.

78 HR-HDA-313-ZUND, kut. 464, Dopis tvornice Velebit, tvornica trikotaže i pletene robe d.d. Zemaljskoj upravi narodnih dobara od 10. rujna 1945.

79 HR-HDA-313-ZUND, kut. 464, Dopis Zemaljske uprave narodnih dobara Ministarstvu industrije i rudarstva, Odjelu za tekstil i kožu, od 27. prosinca 1945. broj 30842/45.-III/3.
} 
Nadalje, iz izvještaja Upravnoga odjeljenja Ministarstva industrije Komisiji za narodnu imovinu Vlade FNRJ, a u svezi s općim podacima za poduzeće Velebit, zapaženo je da je jedan od vlasnika za vrijeme okupacije bio ustaški časnik Josip Tomljenović. No imovinsko-pravni odnosi u vrijeme sekvestracije kazuju nam da su 1946. dvije trećine vlasništva Ljudevita Blaua i Eugena Bartoša darovane novoj vlasti, a jedna trećina vlasništva Hinka Blaua stavljena je pod sekvestar. ${ }^{80}$

Zapisnik sastavljen uime Kotarskoga narodnog suda u Karlovcu u pogledu sekvestracije trećine imovine vlasništva Eugena Bartoša od 18. srpnja 1945., a uslijed odluke Suda za zaštitu nacionalne časti od 14. srpnja 1945., daje nam uvid u popis cjelokupne imovine u obliku pokretnina i nekretnina. U nastavku zapisnika vidljiva je izjava vlasnika Eugena Bartoša, koji je tvrdio da su zapisnikom popisane pokretnine i nekretnine oduzete u NDH trećinskom vlasniku Eugenu Bartošu i predane u vlasništvo ustaškom časniku Josipu Tomljenoviću iz Zagreba. Polovicu dobivenih nekretnina Tomljenović je zadržao za sebe, a drugu polovicu predao na korištenje Mati Serdaru, podrijetlom iz Perušića. Eugenu Bartošu priopćeno je da je sva popisana imovina poduzeća u obliku pokretnina i nekretnina stavljena pod kontrolu državne uprave, a u dogovoru s izaslanikom DUND-a predana joj je uprava i rukovođenje nad tvornicom i imovinom do daljnje odluke suda. ${ }^{81}$

Prema zapisniku Okružnoga suda u Karlovcu od 19. siječnja 1946., Ljudevit Blau izjavljuje da želi darovati svoju trećinu vlasništva poduzeća Velebit Federalnoj Državi Hrvatskoj. U dijelu teksta zapisnika navodi se da je Ljudevit Blau za vrijeme okupacije bio zatočenikom logora na području Njemačke te da želi postupiti kao i njegov partner suvlasnik Eugen Bartoš, koji je svoju suvlasničku trećinu darovao Federalnoj Državi Hrvatskoj darovnim ugovorom od 6. rujna 1945. godine. Suvlasnički dio nekretnina, koji se sastoji od trećine, upisan je u gruntovnom listu broj 1046 Kotarskoga okruga Banija, na kojem se nalaze tvornički objekti Blau i Bartoš tvornica proizvoda pletene robe, Karlovac. ${ }^{82}$

\section{Zaključak}

Nakon završetka Drugoga svjetskog rata na teritoriju Karlovca i Hrvatske u okviru novoustrojene DFJ, a nedugo zatim i FNRJ, provedeno je podržav-

\footnotetext{
80 HR-HDA-313-ZUND, kut. 464, Dopis Upravnog odjeljenja Ministarstva industrije Komisiji za narodnu imovinu Vlade FNRJ od 3. prosinca 1946.

81 HR-HDA-313-ZUND, kut. 464, Zapisnik sastavljen uime Kotarskog narodnog suda u Karlovcu broj IIb-K-83/45. od 18. srpnja 1945.

82 HR-HDA-313-ZUND, kut. 464, Zapisnik Okružnog suda u Karlovcu broj Su. 49/46-1. od 19. siječnja 1946.
} 
ljenje svih oblika privatnoga vlasništva. U osnovi podržavljenja privatnoga vlasništva bio je ideološki sukob s neistomišljenicima, koje se htjelo lišiti poslovne imovine te vlasnike privatnoga kapitala učiniti ovisnima o novoustrojenim vlastima. Poduzeća konfiscirana na području Karlovca i okolice, prema dostupnoj arhivskoj dokumentaciji, bila su uspješna i s pozitivnim bilancama neposredno prije i za vrijeme rata. Uspješnost poslovanja, koja je potvrđena pozitivnim bilancama, odnosno dominacijom stavki aktive naspram stavki pasive, pozamašna rezervna i prijenosna sredstva te pozitivno stanje blagajni nakon provjere tvorničkih zapisa i dokumentacije izazivali su sumnju u očima novoustrojenih komunističkih vlasti. Sumnja je bila usmjerena na poduzeća i tvornice koji su prema novoustrojenoj zakonskoj proceduri optuženi za suradnju s ustaškim vlastima, kojima su bili vodeći partneri u otkupu sredstava za potrebe Hrvatskih oružanih snaga i ostalih institucija. Konfiskacija na prostoru Jugoslavije bila je postavljena na ekonomskim premisama koje su za cilj imale obračun s ideološkim neistomišljenicima u duhu socijalističke revolucije, za čije je provođenje konsenzus postojao od 1920., kada je osnovana KPJ. Zaključno, konfiskacija provođena na opisani način stvorila je ozračje straha i obračuna s političkim neistomišljenicima te omogućila dominantnu ulogu KPJ u upravljanju društvenim procesima. 


\section{Arhivska građa}

HR-HDA-313-ZUND: Hrvatska, Hrvatski državni arhiv, Zagreb, fond 313, Zemaljska uprava narodnih dobara Narodne Republike Hrvatske.

HR-HDA-367-RZSSRH-19: Hrvatska, Hrvatski državni arhiv, Zagreb, fond 367, Republički zavod za statistiku Socijalističke Republike Hrvatske, Zavod za statistiku (1875. - 1948.), Analitički inventar, Gospodarska statistika, kut. 19.

\section{Literatura}

AKMADŽA, Miroslav. Oduzimanje imovine Katoličkoj crkvi i crkveno-državni odnosi od 1945. do 1966. godine. Primjer Zagrebačke nadbiskupije. Zagreb: Društvo za povjesnicu Zagrebačke nadbiskupije „Tkalčić”, 2003.

ANIĆ, Tomislav. „Normativni okvir podržavljenja imovine u Hrvatskoj/Jugoslaviji 1944.-1946." Časopis za suvremenu povijest 39 (2007), br. 1: 25-62.

ANIĆ, Tomislav. „Podržavljenje stranog kapitala u Hrvatskoj/Jugoslaviji 1945.-1946. na primjeru poduzeća Thonet Mundus d.d. u većinskome švicarskom vlasništvu”. Časopis za suvremenu povijest 40 (2008), br. 3: 819-832.

BILANDŽIĆ, Dušan. Hrvatska moderna povijest. Zagreb: Golden marketing, 1999.

KOLAR-DIMITRIJEVIĆ, Mira. „Privredni razvoj Karlovca između dva rata”. U: Karlovac 1579-1979, ur. Tomislav Majetić, Katica Miholović, Đuro Zatezalo. Karlovac: Historijski arhiv u Karlovcu, 1979, 227-238.

MATICKA, Marijan. „Zakonski propisi o vlasničkim odnosima u Jugoslaviji (19441948)". Radovi Zavoda za hrvatsku povijest Filozofskoga fakulteta u Zagrebu 25 (1992), br. 1: 123-148.

MIKOLA, Milko. Zaplembe premoženja v Sloveniji 1943-1952. Celje: Zgodovinski arhiv, 1999.

RADELIĆ, Zdenko. Hrvatska u Jugoslaviji 1945. - 1991. Od zajedništva do razlaza. Zagreb: Školska knjiga; Hrvatski institut za povijest, 2006.

ŠIMONČIĆ-BOBETKO, Zdenka. Industrija Hrvatske 1918. do 1941. godine. Zagreb: AGM, 2005. 


\section{SUMMARY}

\section{Confiscation of the Textile Industry in Karlovac from 1945 to 1946}

The topic of this paper are the economic processes initiated through political decisions in Karlovac and its surroundings after World War II, from 1945 to 1946. In a wider context of economic relations, the focus is on the confiscation of the textile industry in Karlovac and its surroundings as a leading initiator of economic development in the mentioned area. Confiscation, through judicial government, meant taking private property away by force with the aim of collectivising property for the needs of the central unitarist and totalitarian government. After studying the available documentation, it is obvious that the most successful companies in the textile industry, but not only them, became the state's property via judicial decisions. After that, the state, through its administrative and central way of governing, made all important business decisions related to the confiscated companies as well as directly about the economic situation in the whole country. Moreover, it is important to emphasise that confiscation was one of the ways used to punish pre-war and wartime political opponents. It was also a way of making them unimportant in social relations, and finally making them dependent on the central government, which, as I have already stressed, dictated political and economic processes on all levels.

Key words: Karlovac; 1945-1946; confiscation; textile industry 